\title{
STOMATOLOGIC STATUS IN PATIENTS WITH MALIGNANT NEOPLASMS OF MAXILLOFACIAL REGION UNDERGOING CHEMOTHERAPY AND RADIOTHERAPY
}

\section{Olga Shpulina, Natalia Dorofeeva, Lugansk State Medical University, olga.shpulina@mail.ru}

The aim of this study was to evaluate the early acute side effects following radiation and chemotherapy in patients with head and neck cancer (HNC), namely: to ascertain main patient complaints; to investigate saliva properties and to determine the microecology of the oral cavity in patient with $\mathrm{HNC}$ before and after radiation and chemotherapy. Eighteen patients with HNC which were prescribed gamma therapy on two buccal submandibular fields combined with close-focus roentgenotherapy and methotrexate as a cytostatic were examined. It was established that 3 weeks after the radio- and chemotherapy $100 \%$ of patients pointed at xerostomia, dysgeusia, disturbances during speech, burning, pricking and itching in oral cavity. After cancer treatment the speed of salivation decreased two times and $\mathrm{pH}$ was $15 \%$ lower than before radio and chemotherapy. Anti-cancer treatment caused significant decrease of lysozyme level (34 \% lower) and secretory immunoglobulin A (1,5 times lower) in patients with HNC. After radio and chemotherapy different fungi of Candida genus from oral cavity were inoculated in high concentrations (from 4,0 \pm 0.07 to $6,9 \pm 0.07 \mathrm{lg} \mathrm{CFU} / \mathrm{ml}$ ), such as C. Albicans, C. Kruzei, C. Tropicalis, C. Stellatoidea. Thus significant negative changes from the side of speed and character of salivation, decrease of saliva $\mathrm{pH}$, depression of both non-specific and specific components of immune defense and high contamination of oral mucosa with fungi of Candida genus considerably worsen post-cancer rehabilitation.

UDC Numbers: 616.31, 615.28 - 849, DOI: 10.12955/cbup.2013.46

Keywords: cancer, radiotherapy, chemotherapy, xerostomia, candidosis

\section{Introduction}

During last years the continuous increase of cancer rate in different regions of the world is observed. Each year in Ukraine there are discovered about 160 thousand of new cases of cancerous diseases and almost 100 thousand patients die due to malignant pathology (Fedorenko, 2011). Every year about 400000 cases of head and neck cancer (HNC) are diagnosed in the world (Bonifazi et al., 2011) and among this cases the first place takes the cancer of oral mucosa that is $8,8 \%$ per 100000 of population of Ukraine (Bondarenko, 2011).

The most effective methods of treatment of cancerous diseases are radical ones which include surgical treatment, radiotherapy and chemotherapy (Chissov \& Davydov, 2008). Despite their high antitumoral potential these methods cause significant pathologic changes in different body organs and systems. Side effects of radio- and chemotherapy are particularly manifested in oral cavity (Fedyaev et al., 2000; Grau et al., 1995; Ozsahin et al., 2007; Pilecki et al., 1997). According to scale of 
radiosensitivity by Holthusen and Desjardins epithelium of mucous membrane takes the fourth place after lymphoid tissue, thymus and bone marrow (Shashkov, Jarmonenko \& Vainson, 2004). There are about 400000 patients each year in Ukraine that suffer from complications after cancer treatment manifested in oral mucosa (Katchmar et al., 1997).

Thus, the aim of this study was to evaluate the early acute side effects following radiation and chemotherapy in patients with HNC. The specific goals of the study were: to ascertain main patient complaints; to determine the speed of saliva secretion, its $\mathrm{pH}$ level and the indices of non-specific and specific resistance factors in oral liquid before and after radiation and chemotherapy; to determine the microecology of the oral cavity in patient with $\mathrm{HNC}$ before and after anticancer treatment.

\section{Data and research methodology}

Eighteen patients with HNC were examined: squamous cell carcinoma of mucous membrane of the tongue (11 patients), and mucous membrane of sublingual area (7 patients). Patients were prescribed gamma therapy on two buccal submandibular fields (summary cumulative dose was 40-45 Gy) combined with close-focus roentgenotherapy (summary dose was 40-60 Gy) and methotrexate was prescribed as a remedy for cytostatic treatment.

The study was conducted directly before the start of anticancer treatment and 3 weeks after the last day of treatment. Saliva samplings were taken from all the participants during the same time, between 11 and 12 o'clock in order to eliminate the influence of diurnal rhythm of oscillations on observable indices. Saliva was gathered in measuring centrifuge tubes with $0.1 \mathrm{ml}$ of division value during 20 minutes. Speed of non-stimulated salivation is equal to general volume of taken saliva devided on 20 and is expressed in $\mathrm{ml} / \mathrm{min}$.

For further immunologic survey tubes were hermetically closed and centrifuged with temperature + 3$5^{\circ} \mathrm{C}$. Liquid phase was used for detection of phase of lysozyme activity and immunoglobulin content. Studies of immunoglobulin were conducted according to method of radial immunodiffusion by Manchini et al. (1965) in modification of Simmons (1971) with use of antiserum to secretory immunoglobulin A and microplates. For study of lysozyme activity in mouth liquid method of Gorin et al. (1971) was used.

To confirm the diagnosis of fungous stomatitis in patients after anticancer treatment microscopic technique (express diagnostics) and Saburo's special selective bacterial medium inoculation of pathologic material from oral mucosa were used. Also there was detected the number of viable organisms by count of colony-forming units which was determined by decimal logarithm (lgCFU) in appropriate quantity of inoculated material (Engelkirk \& Duben-Engelkirk, 2008).

$\mathrm{pH}$ of mouth liquid was evaluated with the help of mini pH tester IQ-125 (made in USA). Received results were statistically processed with the help of Student's t-distribution (Stanton, 2005).

\section{Results}

3 weeks after the radio- and chemotherapy $100 \%$ of patients pointed at xerostomia, presenting the next complaints: excessive thirst and consumption of liquid, deglutitive problems, frequent use of remedies supporting the humidity in oral cavity (chewing the bubble gum, taking the sour sweets), 
dysgeusia, disturbances during speech, labial fissures, problems in wearing prostheses, burning, pricking and itching in oral cavity. More viscous and syrupy mouth liquid, difficulties in getting the saliva from ducts of greater salivary glands, lost of glitter in oral mucosa, it becomes thin and pale, angular cheilitis, candidosis manifested in smooth red macules, diffuse areas of bright red color, removable white and grayish-beige plaques or white ones non-removable in scaling.

Assessment of hygienic condition of the oral cavity in patients after radio- and chemotherapy is $2,5 \pm 0.23$ according to Green-Vermillion index; it is the evidence of unsatisfactory state of hygiene and complications in individual oral care in patients after cancer treatment (see Table 1). During the study of saliva physical properties it was detected that after cancer treatment the speed of salivation decreases two times and $\mathrm{pH}$ is $15 \%$ lower than before radio and chemotherapy.

As it was illustrated by results of the study, radio- and chemotherapy cause significant decrease of lysozyme level (34 \% lower) and secretory immunoglobulin A (1.5 times lower) in patients with HNC.

Table 1: The state of saliva in patients with head and neck cancer before and after cancer therapy

\begin{tabular}{|c|c|c|c|c|c|}
\hline & $\begin{array}{c}\text { Green- } \\
\text { Vermillion } \\
\text { index }\end{array}$ & $\begin{array}{c}\text { Speed of } \\
\text { salivation } \\
(\mathrm{ml} / \mathrm{min})\end{array}$ & $\mathrm{pH}$ of saliva & $\begin{array}{c}\text { Lysozyme } \\
\text { activity (mcg/l) }\end{array}$ & $\begin{array}{c}\text { Level of } \\
\text { sIgA (mg/l) }\end{array}$ \\
\hline $\begin{array}{c}\text { Before } \\
\text { radio- and } \\
\text { chemotherapy }\end{array}$ & $1.7 \pm 0.12$ & $0.65 \pm 0.04$ & $6.5 \pm 0.11$ & $353.8 \pm 32.4$ & $0.56 \pm 0.05$ \\
\hline $\begin{array}{c}\text { After } \\
\text { radio- and } \\
\text { chemotherapy }\end{array}$ & $2.5 \pm 0.23$ & $0.32 \pm 0.02$ & $5.5 \pm 0.28$ & $233.5 \pm 23.5$ & $0.38 \pm 0.05$ \\
\hline
\end{tabular}

Notes: all the difference between indexes before and after cancer treatment is statistically reliable $(\mathrm{p}<0.05)$

Source: Authors

Diagnosis of oral candidosis was verified on the ground of the whole set of patients' complaints, quantity of colony-forming units of fungi on oral mucosa belonging to Candida albicans genus on the assumption of exceeding of $3 \mathrm{lg} \mathrm{CFU} / \mathrm{ml}$ and signs of invasion of Candida albicans in oral mucosa.

After radio and chemotherapy different fungi of Candida genus from oral cavity were inoculated in high concentrations, such as C. Albicans, C. Kruzei, C. Tropicalis, C. Stellatoidea (see Table 2).

Quantitative results of their inoculation varied from 3,2 \pm 0.02 to $2,2 \pm 0.03 \mathrm{lg}$ CFU/ml before cancer treatment and from $6,9 \pm 0.07$ to $4,0 \pm 0.07 \mathrm{lg} \mathrm{CFU} / \mathrm{ml}$ after. Most patients had fungi of Candida genus in the form of yeast cells ( $86 \%$ ), pseudomycellium was detected only in $14 \%$ patients.

High concentrations of fungi inoculation in oralmucosa may be the evidence of transient character of fungous seeding of oral cavity. Spectrum of these microorganisms did not have any differences in the samples from cheek and tongue. 
Table 2: The indices of microecology in oral cavity of patients with head and neck cancer before and after cancer therapy $(\lg \mathrm{CFU} / \mathrm{ml})$

\begin{tabular}{|c|c|c|c|c|c|c|c|c|c|}
\hline \multirow{3}{*}{$\#$} & \multirow{3}{*}{$\begin{array}{l}\text { Type of } \\
\text { microorga- } \\
\text { nism }\end{array}$} & \multicolumn{4}{|c|}{ Before radio- and chemotherapy } & \multicolumn{4}{|c|}{ After radio- and chemotherapy } \\
\hline & & \multicolumn{2}{|c|}{ Cheek } & \multicolumn{2}{|c|}{ Tongue } & \multicolumn{2}{|c|}{ Cheek } & \multicolumn{2}{|c|}{ Tongue } \\
\hline & & $\begin{array}{c}\text { Superficial } \\
\text { layer }\end{array}$ & Scrape & $\begin{array}{c}\text { Superficial } \\
\text { layer }\end{array}$ & Scrape & $\begin{array}{l}\text { Superficial } \\
\text { layer }\end{array}$ & Scrape & $\begin{array}{c}\text { Superficial } \\
\text { layer }\end{array}$ & Scrape \\
\hline 1 & C. Albicans & $2.7 \pm 0.05$ & $3.2 \pm 0.04$ & $3.2 \pm 0.02$ & $3.0 \pm 0.04$ & $4.2 \pm 0.03 *$ & $4.8 \pm 0.05^{*}$ & $6.3 \pm 0.02 *$ & $\begin{array}{l}6.9 \pm 0.07 \\
*\end{array}$ \\
\hline 2 & C. Kruzei & $2.2 \pm 0.03$ & $2.4 \pm 0.06$ & $2.7 \pm 0.04$ & $2.8 \pm 0.05$ & $4.0 \pm 0.07^{*}$ & $4.2 \pm 0.03^{*}$ & $4.4 \pm 0.05^{*}$ & $\begin{array}{l}5.7 \pm 0.04 \\
* / * *\end{array}$ \\
\hline 3 & C. Tropicalis & $2.3 \pm 0.07$ & $2.6 \pm 0.02$ & $2.5 \pm 0.04$ & $2.6 \pm 0.04$ & $4.5 \pm 0.02 *$ & $4.8 \pm 0.04^{*}$ & $4.7 \pm 0.03 *$ & $\begin{array}{l}5.3 \pm 0.05 \\
*\end{array}$ \\
\hline 4 & C. Stelatoidea & $2.4 \pm 0.02$ & $2.2 \pm 0.04$ & $2.7 \pm 0.03$ & $2.5 \pm 0.05$ & $4.1 \pm 0.04^{*}$ & $4.2 \pm 0.06^{*}$ & $4.5 \pm 0.03 *$ & $\begin{array}{l}5.3 \pm 0.07 \\
*\end{array}$ \\
\hline
\end{tabular}

Notes:

1. * - statistically reliable difference between indices received from material belonging to patients before and after radio- and chemotherapy $(\mathrm{p}<0.05)$;

$2 . *^{*}$ - statistically reliable difference between indices received from material belonging to superficial and deep layer of oral mucosa $(\mathrm{p}<0.05)$.

Source: Authors

\section{Conclusion}

Thus, significant negative changes from the side of speed and character of salivation, decrease of saliva $\mathrm{pH}$, depression of both non-specific and specific components of immune defence are observed in oral cavity of HNC patients which underwent radio and chemotherapy. At the same time application of radio and chemotherapy in these patients considerably increases contamination of oral mucosa with fungi of Candida genus so that it is manifested by apparent clinical picture of candidosis and worsens post-cancer rehabilitation. The patients undergoing radio- and chemotherapy on account of HNC require regular professional oral hygiene and appropriate correction of salivation, local immunity and microecology.

\section{References}

Bondarenko, S. H. (2011). Puti uluchsheniya rezultatov lecheniya u patsientov s rakom slizistoy obolochki polosti rta [The ways of improvement of treatment results in patients with cancer of oral mucosa]. Clinical oncology, 11, 29.

Bonifazi, M., Malvezzi, M., Bertuccio, P., Edefonti, V., Garavello, W., Levi, F., La Vecchia, C. \& Negri, E. (2011). Age-period-cohort analysis of oral cancer mortality in Europe: the end of an epidemic? Oral Oncology, 47 (5), 400-407. http://dx.doi.org/10.1016/j.oraloncology.2010.06.010 PMid:21402489

Chissov, V. I. \& Davydov, M. I. (2008). Onkologiya: Natsionalnoe rukovodstvo [Oncology: National Guide]. Moscow, Russia: Geotar Media. 
Engelkirk, P. G., \& Duben-Engelkirk, J. (2008). Laboratory diagnosis of infectious diseases: essentials of diagnostic microbiology. Philadelphia, PA: Lippincott Williams \& Wilkins.

Fedorenko, Z. P. (2001). Kontyngenty xvoryx na zloyakisni novoutvorennya v Ukrayini — ocinka povnoty ta yakosti informaciyi [Evaluation of completeness and quality of data about cancer patients registered under follow-up in Ukraine]. Clinical oncology, 3 (3), 4-8.

Fedyaev, E. M., Bairikov, I. M., Belova, L. P. \& Shuvalova, T. V. (2000). Zlokachestvennyie opuholi chelyustno-litsevoy oblasti [Malignant Tumors of the Maxillofacial Area] Moscow, Russia: Meditsinskaya kniga.

Glantz, S. A. (2005). Primer of biostatistics. New York, NY: McGraw-Hill Medical Pub.

Gorin, G., Wang, S. F. \& Papapavlou, L. (1971). Assay of lysozyme by its lytic action on M. lysodeikticus cells. Analytical Biochemistry, 39 (1), 113-27. http://dx.doi.org/10.1016/00032697(71)90467-2

Grau, J. J., Estape, J., Traserra, J., Galan, M. \& Daniels, M. (1995). Cure rate after long-term followup in head and neck cancer. European Journal of Cancer, 31 (6), 88-9.

http://dx.doi.org/10.1016/0959-8049(95)95660-X

Katchmar, T. B., Bilynsky, B. T., Domenqe, C., Kramar, A. \& Shparik, J. (1997). Neoadjuvant chemotherapy before radiotherapy of advanced head and neck cancer in Ukraine. European Journal of Cancer, 33 (8), 190. http://dx.doi.org/10.1016/S0959-8049(97)85537-2

Manchini, C., Carbonare, A. \& Haremans, I. F. (1965). Immunochemical quantitation of antigens by single radial immunodiffusion. Immunochemistry, 2, 234-35.

Ozsahin, M., Pehlivan, B., Matzinger, O., Luthi, F., Bron, L., Pasche, P., Seelentag, W., Bulling, S., Mirimanoff, R. O. \& Zouhair, A. (2007). Accelerated weekly concomitant boost postoperative radiation therapy combined to concomitant chemotherapy in patients with locally advanced head and neck cancer. European Journal of Cancer Supplements, 5 (4), 324-5. http://dx.doi.org/10.1016/S13596349(07)71219-3

Pilecki, B. \& Skladowski, K. (1997). Estimation of the influence of biological modyfires on severity of acute mucosal reaction in patients with head and neck cancer. European Journal of Cancer, 33 (8), 190. http://dx.doi.org/10.1016/S0959-8049(97)85536-0

Shashkov, V. S., Jarmonenko, S. P. \& Vainson A. A. (2004). Radiobiologiya cheloveka i zhivotnyih [Radiobiology of human and animals]. Moscow, Russia: Higher School.

Simmons, P. (1971). Quantitation of plasma in law concentration using RID. Clinica Chimica Acta, 35, 53-7. http://dx.doi.org/10.1016/0009-8981(71)90292-0 